\title{
Effect of potassium and sulphur levels on nodulation quality aspects and yield attributes of Rabigroundnut
}

S. M. Kharwade and N. R. Mairan

Received : 17.10.2019; Revised : 12.11.2019; Accepted : 21.11.2019

\author{
MEMBERS OF RESEARCH FORUM: \\ Corresponding author : \\ S. M. Kharwade, Department of \\ Soil Science and Agricultural \\ Chemistry, Vasantrao Naik \\ Marathwada Krishi Vidyapeeth, \\ Parbhani (M.S.) India \\ Email: nishapati17806@gmail.com
}

\section{Co-authors :}

N. R. Mairan, Department of Soil Science and Agricultural Chemistry, Vasantrao Naik Marathwada Krishi Vidyapeeth, Parbhani (M.S.) India

\section{Summary}

A field experiment was conducted in the plot no. A-8 at college farm Department of Agronomy, VNMAU, Parbhani during Rabi season of year 2001-2002.The experiment was laid in a split plot design with 16 treatment combination. Four levels of each potassium and sulphur were taken each treatment was replicated three times. The quality parameter i.e. oil content, oil yield and crude protein content of groundnut kernel also showed significant response to potassium and sulphur levels. The response in term of pod and kernel yield was maximum at $50 \mathrm{~kg} \mathrm{k}_{2} \mathrm{O} / \mathrm{ha}$.

Key words : Potassium, Sulphur, Groundnut quality aspect

How to cite this article : Kharwade, S.M. and Mairan, N.R. (2019). Effect of potassium and sulphur levels on nodulation quality aspects and yield attributes of Rabi groundnut. Asian J. Soil Sci., 14 (1\&2) : 57-62 : DOI : 10.15740/HAS/AJSS/14.1and2/57-62. 